\title{
Tokidoki, Cute and Sexy Fantasies between East and West: Contemporary Aesthetics for the Global Market
}

\author{
Emiko Okayama, Macquarie University, and Francesco Ricatti, University of the \\ Sunshine Coast
}

The perceived privileged relationship between Italian art and the nation has been rarely challenged by intellectuals since the unification of the state. This is despite the extraordinary diasporic history of Italy: a history of immigrations, emigrations, invasions, exiles, colonialisms, and fragmentations. Furthermore, this history includes the migration and exile of many representative artists. Noteworthy is the case of Italian literature, which is often interpreted and taught as the constituent element of the nation and its language. One of the most important critical goals of contemporary Italian cultural studies is to challenge this privileged relation, by means of theoretical approaches that consider the essential features of globalisation and 'modernity at large' (Appadurai 1996). Within this context, and from this theoretical perspective, we examine the work of Simone Legno, an Italian designer who works in the USA and is strongly influenced by Japanese art and culture (Figure 1). ${ }^{1}$

Simone Legno's work, which essentially consists in designing and commercialising his personal fantasies of Japan and Japanese women, has been highly successful in the USA and Europe, as well as in many Asian countries, including Japan, Hong Kong and Thailand. Legno's work thus challenges received ideas about contemporary Italian art and design, and global cultural trends in contemporary capitalism. In particular his work

\footnotetext{
${ }^{1}$ The copyright of all images in this article is held by Tokidoki and Simone Legno; the images are published here courtesy of Simone Legno.
} 


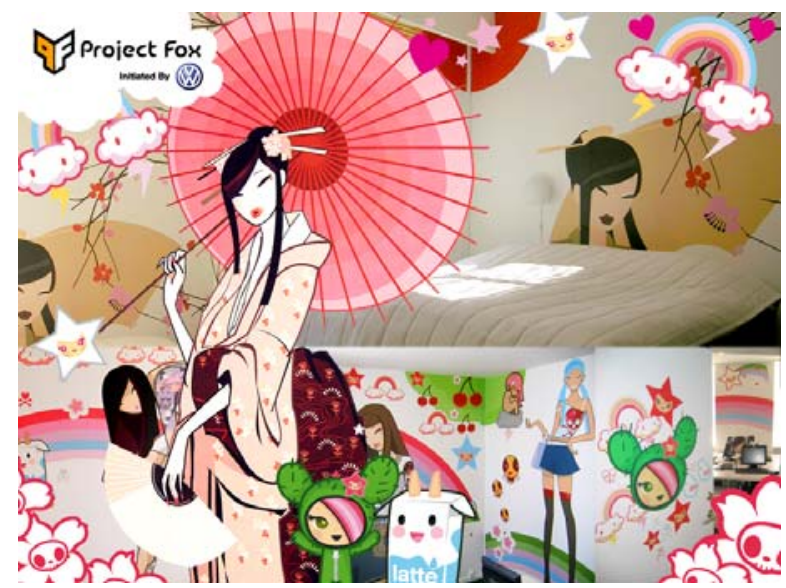

Figure 1: Simone Legno, Project Fox for Volkswagen, image courtesy of the artist.

poses questions regarding what could be defined as gendered Orientalism, the typical attempt to romanticise the Orient through Oriental women, and the old but persistent and pervasive male Western stereotype of Oriental women as 'submissive, subservient, [and] exotic' (Prasso 2005: 8). While Legno's representation of Japanese women as beautiful, sexy, self-confident, and innocently licentious, yet also sweet and reassuring, is partially consistent with some aspects of gendered Orientalism, we argue that Legno's Tokidoki needs to be framed in terms of the present global diaspora and hybridisation of cultural signs and symbols, thus requiring a broader critical approach than that provided by the critique of Orientalism.

As Ravi, Goh and Rutten (2004: 2) suggest, it is essential to challenge the 'centreperiphery conception of Europe-Asia relations' particularly when focusing on the recent evolution of globalisation. Following the lesson of Bhabha (1994), we avoid considering Legno’s work as a unilateral projection of Western fantasies onto or about the Orient, and focus instead on the reciprocal and complex cultural and economic influences that link Japan, Italy and the USA. As Goh argues:

\footnotetext{
The disruptions opened up by recent interrogations of Western and non-Western modernity and the ways in which these experiences are made to appear distinct under the aegis of various type of agency across time and space not only forces a recognition of new modern imaginaries, practices and categories but also challenge us to think of how, now more than ever, the contemporary world offers occasions for a dialectical encounter between the West and non-West. (2004: 95)
}

Due to the global and decentered nature of contemporary capitalism, it is increasingly important to consider the in-between of different cultures (Hall 2000). To see cultural identities as 'a matter of "becoming” as well as of "being”' (23) implies that Anderson’s 
notion of imagined communities (1992) must be considered not only from within-for example, Italy inventing Italy, Japan inventing Japan—but also from transnational and global perspectives. Here the concept of locality within globalisation is central. For Appadurai (1996) locality is both deterritorialised and invented. He (2003: 39) uses the example of Asian martial arts in Hollywood and the Hong Kong film industry to illustrate how Asian traditions can create new transnational cultures of masculinity.

Tokidoki and its success operate similarly in creating new cultures of femininity out of Japanese artistic forms of production and distribution as reinvented by an Italian designer within a global economy. While these new cultures of femininity could be read simply as being new Euro-American projections of an orientalised femininity (or a feminised Orient), we argue for the importance of reading such phenomena as the fruits of reciprocal, complex and ambiguous influences between different cultures within contemporary capitalism and global consumerism. Iwabuchi suggests that we need to bear in mind 'the shifting nature of transnational cultural power' that determines decentering and asymmetrical cultural flows (2002: 39).

Tokidoki was originally created by Simone Legno in the late 1990s on his personal website (www.tokidoki.it), which he continues to use as an online portfolio to showcase his graphic work. Between 1999 and 2006 Legno was the creative director of Vianet (www.vianet.it), a successful new media design company that has worked with advertisement companies, such as Leo Burnett and Saatchi and Saatchi, and has designed web sites and other new media projects for multinational companies, such as MTV, Sony, Toyota, Fiat and Renault. Many of these projects were characterised by exotic representations of Asian women, and advertised European and Japanese products for the Italian and European Market. ${ }^{2}$ However, Vianet has also developed many projects for an Asian audience. ${ }^{3}$

In 2003, Simone Legno moved to Los Angeles and, together with one of the founders of Hard Candy Cosmetics, transformed Tokidoki into a fashion label. Todidoki is now an

\footnotetext{
${ }^{2}$ See, for instance, the project Fox for Volkswagen (http://www.vianet.it/clienti/projectfox), the advertisement for Daihatsu in Italy (http://www.vianetlab.com/Daihatsu/), and the awards winning project for BenQ in Europe.

${ }^{3}$ See, for instance, The Way Out, a web anime produced for the Central Narcotics Bureau of Singapore (http://www.vianetlab.com/CNB/).
} 
established brand and its products have been produced, distributed and sold in collaboration with companies such as Sanrio, LeSportSac and Fornarina. ${ }^{4}$ Products designed by Legno for Tokidoki include clothes, bags, jewellery, toys, watches, and uchiwas (Japanese fans for women). These products are distributed in Asia, North America, Europe and Australia. In our correspondence with Ivan Arnold, Tokidoki's president, Arnold emphasised how 'the success and proliferation [of Tokidoki] has been unprecedented.' He also remarked that Tokidoki does not target a specific group of customers. While it is particularly popular with young Asian women both in Asian and Western countries, its general audience is 'as diverse as anything we could ever imagine, including pretty much every race and every age.' A sign of the brand's success is the ease with which fake reproductions of Tokidoki's products can be purchased in many countries, as well as on the internet.

Legno has declared that he has a particular love for Japan, 'from the ultra modern face of Shibuya to the serious magic silence of Kyoto' (Legno n.d. About: para. 2). However, this personal fascination needs to be set in context, given the huge influence of anime (Japanese cartoon) in Italian culture, particularly for the generation of Italians, such as Legno, born in the 1970s. Many important Japanese artists, writers and cinematographers are well known in Italy, including Katsushika Hokusai, Murakami Takashi, Tanizaki Jun’ichiro, Murakami Haruki, Yoshimoto Banana, Kurosawa Akira, and Kitano Takeshi. ${ }^{5}$ However, the most influential aspect of Japanese culture for the generation of Italian children born in the 1970s was the broadcasting on TV of Japanese cartoons, although edited and dubbed. Italy was one of the first European countries to import anime. From 1977 to the early 1980s more than 100 anime series were broadcast on Italian public and private TV channels at national and local levels (Castellazzi 1999). Italian fans of anime have been recently able to recall almost 400 anime broadcasts in Italy. ${ }^{6}$ While these cartoons were strongly criticized by some sections of the public, most Italian children and adolescents born in the 1970s watched anime many hours a day for many years (Castellazzi 1999; Pellitteri 2002; Raffaelli 2005). The generation of Simone Legno often identifies and defines itself through these cartoons and through the first home videogames. Many Italians of the same generation as Legno are still able to

\footnotetext{
${ }^{4}$ See: http://www.tokidoki.it/collaborations/.

${ }^{5}$ In this essay Japanese names are written with surname first followed by a personal name (e.g. Murakami Takashi rather than Takashi Murakami) following the Japanese convention.

${ }^{6}$ See: http://digilander.libero.it/francescaromana1/Lista_anime.html.
} 
sing hundreds of Italian jingles that opened and closed each episode of these Japanese cartoons (Benecchi 2005). While the actual cultural and social impact of these products on Italians has not been deeply investigated, there is no doubt that the Japanese society represented in those anime still exercises a strong fascination for young and middle aged Italians. Despite the strong editing and the not always faithful translations made by the Italian TV channels, elements of Japanese culture have now been at the core of Italian childhood for almost thirty years. These cartoons, as broadcast in Italy, are the hybrid product of Japanese cartooning and Italian editing, translating, dubbing and songs. Moreover, if Legno’s generation was the first and perhaps the most influenced by these products, the same generation later became the target for the commercialisation of manga in Italy and other Western countries.

Japanese anime and manga (as well as video games) are relevant not only for the impact they have had on Legno’s design, but also for the emotional attachment that his references to Japan can create for consumers from Italy and other countries who grew up watching cartoons and reading manga. It has been argued that these products have become part of a common global culture in which Japan plays a very significant role (see Allison 2004: 36; Iwabuchi 2002).

When considering how specific aspects of Japanese culture influence Legno’s work today, it is essential to shift the focus towards two key and strongly related trends in contemporary Japanese culture and design: the blurring of the distinction between high and popular culture; and the emergence of the kawaii aesthetic. The former trend is a global phenomenon that has found fertile ground in Japan, thanks to artists such as Murakami Takashi. The latter trend is typically Japanese but has become a global phenomenon, and is iconically illustrated by the products of the Japanese company Sanrio, in particular Hello Kitty merchandising, and the Japanese magazine Cawaii!

Murakami Takashi became internationally recognised in 2003 when his life-size figure Miss $K o^{2}$ [sic] was sold at a Sotheby’s auction for US\$500,000, the record price for a work of Japanese modern art at the time. Inspired by modern Japanese subcultures based on anime, manga and otaku, Murakami first received critical acclaim and popularity outside Japan before being 're-exported' to his native country. His recent collaboration with Louis Vuitton, in which he introduced bright colours to traditionally 
monochrome Vuitton products, has been so successful that Vuitton products now attract long waiting lists world-wide. In 2007 New York’s MOCA (Museum of Contemporary Art) opened a large exhibition devoted to Murakami's work that will later travel to Europe. Apart from his own artistic activities, Murakami also manages a group of young artists called Kaikai Kiki, overseeing their exhibitions, coordinating their publicity and managing the production of their merchandise. ${ }^{7}$

The pop side of Murakami has become so famous that few people know of his background in traditional Japanese painting. Murakami was the first $\mathrm{PhD}$ graduate in the discipline of Japanese painting at Tokyo Geijutsu Daigaku (Tokyo National University of Fine Arts \& Music). His work is characterised by duality, and peculiar mixes of seemingly opposite elements. As his 'super-flat' catch phrase indicates, his anime-inspired figures and illustrations are supported by the flatness and structural qualities of traditional Japanese painting that similarly inspired van Gogh, Monet and other modernist painters over a century before. ${ }^{8}$ His collaboration with Louis Vuitton melds art and commercialism, and pop and high culture. In a similar vein is his collaboration with a confectionary company, for which he produced thirty thousand miniature-size figurines of his famously expensive figures, such as $\mathrm{Miss} \mathrm{Ko}^{2}$ and HIROPON (1994), as novelty freebies in packets of sweets that cost only 350 yen (approx. AU\$6.00) each. This is a challenge to conventional concepts of 'what is real' and 'what is art.' The figurines are obviously copies of 'art' but as they are created by the artist and his technical staff, they are at once real and fake. To make the work even more complex, the original life-size figures are also modelled on existing anime and manga characters whose creators were not Murakami. Here, an analogy may be made to one of the 'oldest' Japanese buildings, the Ise shrine. The shrine itself has survived over a thousand years but the group of buildings within the shrine has been periodically rebuilt, as a rule every twenty years, in the same style using the same material and techniques passed on from generation to generation within the same families. Can the current shrine, which is less than twenty years old and a replica of a succession of replicas, be considered authentic? Both the Murakami and Ise shrines, as well as much other Japanese art, challenge the conventional views of authorship and copyright that

\footnotetext{
${ }^{7}$ See: http://www.takashimurakami.com/ and http://english.kaikaikiki.co.jp/artists/list/C4.

${ }^{8}$ Murakami (1999: para 5) states that Japanese aesthetics did not seek three-dimensional expression, but were best expressed on a two-dimensional surface. He further extends 'super-flat' to Japanese social structure and sees it as a characteristic of Japanese cultural sensibilities (Kato 2002: para 3).
} 
are often privileged in the contemporary Western art system.

In a 2003 interview with journalists, Murakami stated that, 'in Japan art has to be accepted by the general public and selling real art as toys at convenience stores is a progress in the long history of art' (Funatsu 2003: para. 6). This blurring of the boundaries between art works and consumer goods also continues a strong Japanese tradition. Edo prints, now treasured as art, were mass-produced and sold for popular consumption. They often bore publicity for kabuki actors and promoted kimonos and other products. In this sense, Murakami's attempt to bring art to a popular domain is a modern continuation of Edo consumerism. Also reminiscent of the Edo art industry is his approach to artistic production through a 'studio,' where he acts as master/producer and business manager and where most works are created by assistants. ${ }^{9}$

Simone Legno has explicitly recognised the influence of Murakami Takashi:

'[Murakami] tamed the chaos of images, icons, characters and inputs to make us all understand how wonderful its essence can be’ (N.d.: Pervasive Persuasion). Legno’s positive words ('understand,' 'wonderful,' and 'essence') need to be emphasised; they indicate how he applies the lesson of Murakami in creating a chaotic world that, nonetheless, is also neat, sweet and reassuring. His use of digital and fashion design, and lively colours that fill clearly defined sections of two-dimensional screens and clothes, has certainly facilitated this goal. The chaos is not a dark hole in which one becomes lost, but a childish flat world where we can, from our external position as amused spectators, spend time looking for cute, little surprises (Figures 2 and 3). Indeed, as Okayama and Shelton state, this is the kind of 'graphic diet upon which young Japanese visual sensibilities are nourished' (2007: 172). Pre-school comics such as Tanoshii Yochien feature wonderfully intricate and dense magazine covers. Various graphic forms — scripts, pictures, anime characters, and hybrid images — crowd their covers' surfaces 'with no dominant centre and no obvious periphery' (Okayama and Shelton 2007: 172). They are 'read' not by linear progression but random scanning; readers return to them again and again for more detailed inspection, and each time

\footnotetext{
${ }^{9}$ Other critics have made similar links between contemporary and Edo processes of art production. For example, the art critics Hikosaka (2008) and Kitani (2001) note the connection between Murakami's studio system and the Kano school painters and the group of anonymous assistants supporting Hokusai.
} 
explore the comics by a different route or series of helicopter-like 'landings,' all of which give viewers long lasting pleasure.

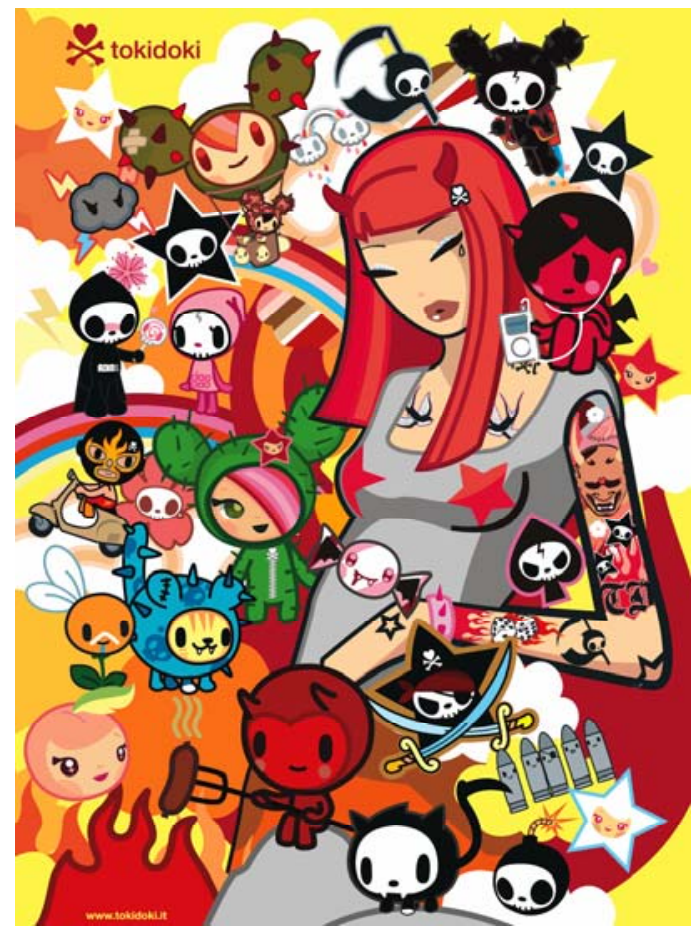

Figure 2. Tokidoki Hell.

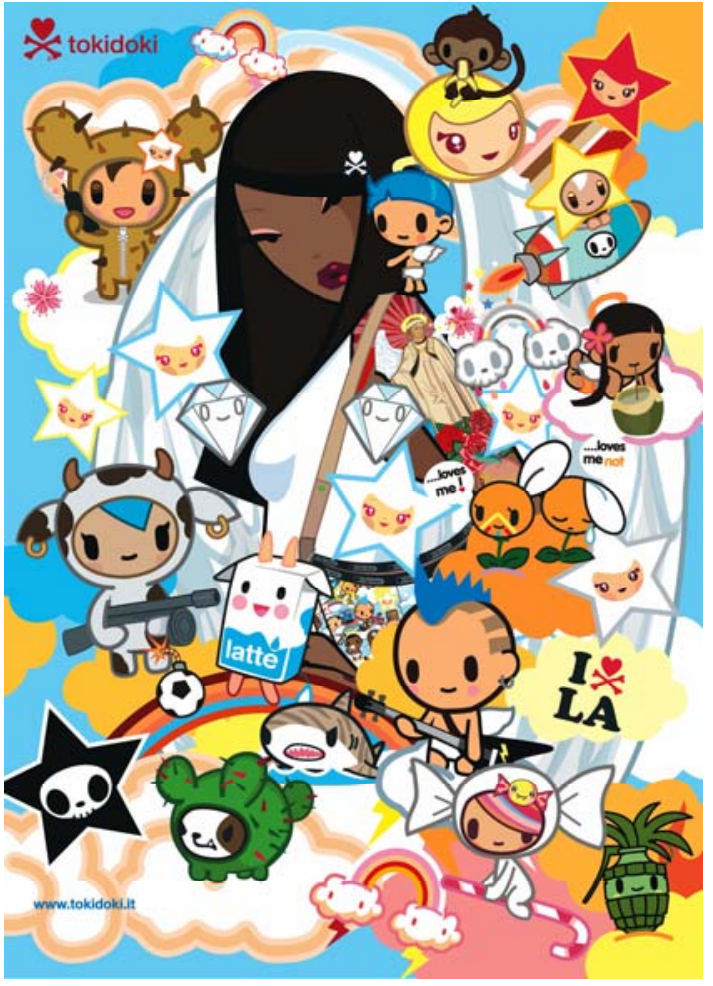

Figure 3. Tokidoki Heaven. 
Another, very important characteristic of Murakami's work that has probably influenced Legno is his attention to commercial opportunities. Legno and his commercial partners have demonstrated their ability in creating business opportunities by exploiting three important characteristics of contemporary design: the hybridisation of high and popular culture and different artistic traditions; the emotional value that design contributes to contemporary consumerism; and design’s global dimension. From the beginning, Legno’s design has attracted the attention of multinational advertisement agencies and companies. His mixture of Italianess and exotic Orientalism has built bridges in the global market between Western companies and Asian consumers, as well as between Asian companies and Western consumers. His interplay between child-like cuteness and sensuality has created a fantastic world where contrasts are avoided and the encounter between different cultures and sensitivities becomes possible.

While Murakami, following the lesson of Warhol, is a representative of high culture playing with popular culture, Legno directly and almost exclusively devotes his work to the design of reproducible clothes and objects. In a sense, the traditional and conservative dichotomy between high and popular culture that still seems to foster media and critical debates about Murakami's art and his commercialisation cannot be applied to Tokidoki. Legno’s creativity and commercial attitude are consistent with the Italian tradition of refined, ironic and sexy design in advertising and for the production of objects to be commercialised. While Legno is fantasising about Japan, his roots in Italian design should, therefore, not be overlooked. Legno is aware of the importance of selling himself as an Italian designer in love with Japan. As one of his fans has argued: 'When Simone creates Tokidoki, it is Japan seen through his eyes and so it is like looking at Japan through Italian binoculars with special lenses' (ToPo 2006: para. 1). In consumerist fantasies, Legno has acquired by birth (that is, by being Italian) the 'right' to be recognised as trendy, stylish, and refined. It is not by chance that Legno's website address (www.tokidoki.it) immediately recalls both Japan (through the word tokidoki) and Italy (through the .it that locates the website). Nor it is by chance that many of Legno's vinyl toys have Italian names such as Bruttino, Carina (Figure 4), Polpettina and Bastardino. His most recent bags also have Italian names, including Luna, Denaro, Buon viaggio, Avventura, Campeggio, Nuvola, Caramella, Trenino (Figure 5), Zucca, Gioco, and Stellina. 


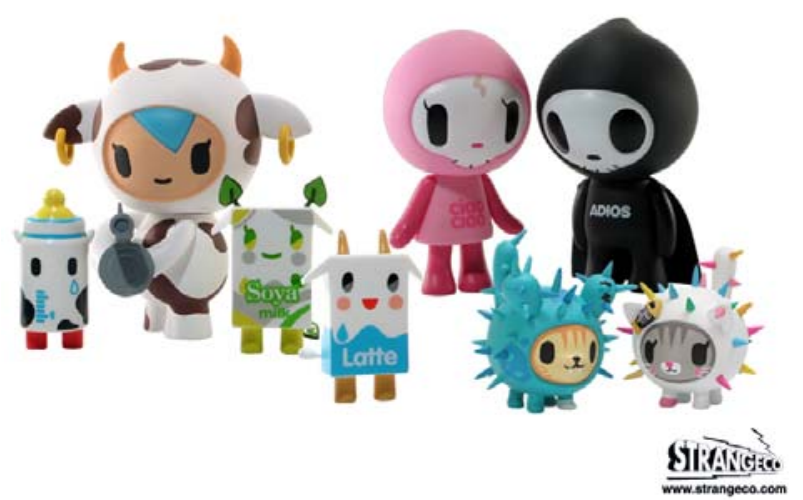

Figure 4. Vinyl toys: Mozzarella and Moofia, Ciao Ciao and Adios, Bruttino and Carina.

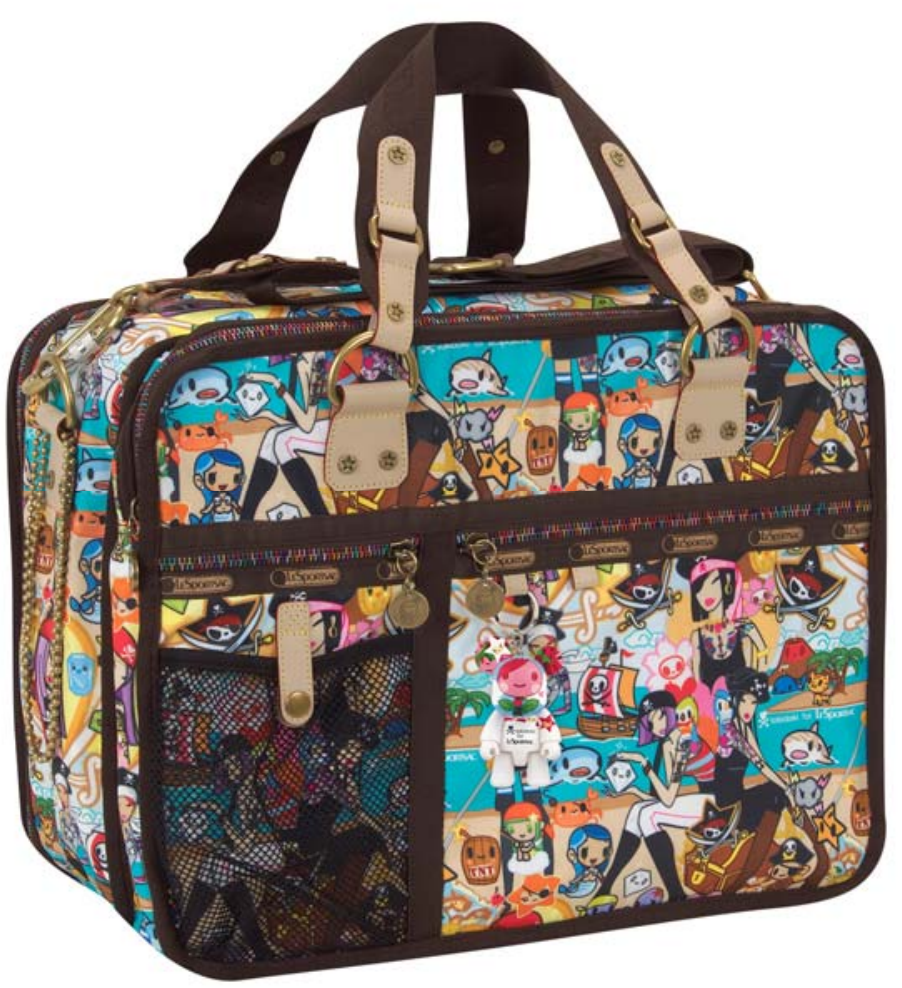

Figure 5. Trenino pirata bag.

Regarding the centrality of the kawaii aesthetic in Legno's work, it is perhaps useful, first of all, to consider critically the role that such an aesthetic plays in contemporary Japan, where it originates. According to the Japanese art historian Yomota (2006: 2936), the word kawayushi (an old form of kawaii) meant 'embarrassing' and 'pitiful' in the twelfth century; but by the sixteenth century it had lost its negative connotation and acquired the meaning of 'lovable,' and was used mainly to refer to small, innocent and 
vulnerable things such as children and small creatures. In the twentieth century, kawayushi transformed into kawayui and then eventually into kawaii: in the process it extended its semantic range to include adults and large animals. These days, kawaii is used for almost everything that is cute, depending on one's sensibility: old men and worms can be kawaii in certain contexts. For example, the philosopher Washida (2004: 57) reports his encounter with some girls at a museum who referred to a display of parasitic worms as kawaii. In this case, kawaii indicates an extremely subjective viewpoint, and connotes 'grotesque’ or 'revolting.' Having developed from 'embarassing' and 'pitiful,' kawaii has repossessed its original meanings without discarding its newer 'cute' and 'lovable' connotations. ${ }^{10}$ Thus, kawaii has a much wider sociocultural meaning and set of uses than 'cute.'

Although Japan has traditionally cherished small and delicate objects and found beauty in them, the popularisation of cute culture has evolved since the 1970s. Kinsella (1995: 223) suggests that the rise of kawaii culture coincided with the cute handwriting craze among young Japanese women that became a nation-wide phenomenon. She states that kawaii culture 'started as youth culture amongst teenagers' and as a rebellion against traditional Japanese culture, whose style is 'all about acting childish' in order to recreate a romanticised childhood (249). Her conclusion is that 'cute style is anti-social, it idolises the pre-social,' and its primal aim is 'to escape from the restrictions governing' the lives of young Japanese women (252). ${ }^{11}$ Her investigation of kawaii culture is insightful in highlighting the historical and social aspects of the trend. However, as Yomota argues (2006: 14), whether young Japanese who are immersed in the kawaii culture are conscious of that culture's political dimensions is highly questionable. He stresses that the uniqueness of Japanese kawaii culture lies in a consistent absence of politics. When asked why they buy kawaii things, most Japanese would answer, 'because they are kawaii.' This sentiment is shared by other Asian youth (mainly Chinese, Korean, Taiwanese and Thais) interviewed at various locations by Koh et al (1999: 54-59) and asked about Japanese products: 'they’re cute, they're in, they have a smart style'; 'they're fun, snazzy and top-quality'; and 'they are so darn cute.' Interestingly enough, these comments recall similar comments from Tokidoki’s fans in

\footnotetext{
${ }^{10} \mathrm{Or}$, to be precise, it never lost its original meanings but has kept its ambiguity.

${ }^{11}$ The US cultural critics Laura Miller (2003; 2004) and Anne Allison (2003; 2004; 2006) have written extensively about the emergence of an ethos of 'kawaii' in Japan. They find in Japanese girls' interactions with 'kawaii' positive qualities, such as playfulness, energy and gender critique.
} 
the USA. For instance, answering to the question 'why is Tokidoki so popular?,' fans on the weblog Purseblog gave the following answers: 'The bags just make me happy'; 'As I always say, they're art ... awesome, functional, wearable art'; 'It's so cute and lovable you just want to hug it!'; 'It’s silly and funny and happy and makes me smile’; 'The artwork is craaazy cute'; 'I dont know ... I like the artwork so much because it's just so cute I can’t resist and I love PINK ... and a lot of the bags have pink haha. I hope this isn’t just some pop culture thing that will fizzle. ${ }^{12}$

There is no doubt that 'cute' is a big money spinner cleverly marketed by industry heavy weights such as Sanrio, Nintendo, and various anime companies. But it is much more than that. Cuteness gives to Japan cultural and economic power on a global scale (Allison 2003). As Koh et al (1999) state, the growing population of Asian fans of Japanese pop culture represents a new generation who either do not know of Japan's past role as a colonial power in the region, or do not care about it. What they see in today’s Japan is its cultural sophistication. A Hong Kong scholar, Lisa Leung, says, 'We're envious of their deep culture. We haven't got much [of that]' (Koh et al 1999: 56). A Hong Kong journalist, Ann Tsang, adds that the Japanese 'have the ability to find the weirdest, most obscure thing and turn it into a trend' (Koh et al 1999: 56). These comments reflect a rising awareness in Asia of cultural closeness between Japan and the recipient countries of its products. Unlike US or European cultural models, Asian youth finds it easier to identify with Japanese pop culture. Dick Lee, the Sony Music Asia vice president, says, 'Mickey Mouse and Donald Duck are not cute ... Pokemon is cute' (Koh et al 1999: 55). He, too, feels more comfortable with Pokemon because it is not entirely foreign to him.

While it is apparent that Tokidoki is characterised by the kawaii aesthetic, the fact that it enjoys great success with a global, heterogeneous audience challenges any attempt to define that audience in national, generational, gendered, or socioeconomic terms. This also makes it difficult to generalise about an anti-social, pre-social or disengaged attitude on the part of Tokidoki's fans. Yet, perhaps, this is precisely what the globalised version of kawaii is all about: creating a child-like yet 'sexy' world where conflicts are avoided through a simple, yet refined and elegant, design. For instance, in the Tokidoki

\footnotetext{
${ }^{12}$ See: http://forum.purseblog.com/tokidoki-and-lesportsac/why-is-tokidoki-so-popular-128933.html.
} 
world the national flags of both Japan and Italy consistently appear as underwear for babies and 'sexy' women alike (Figure 6).

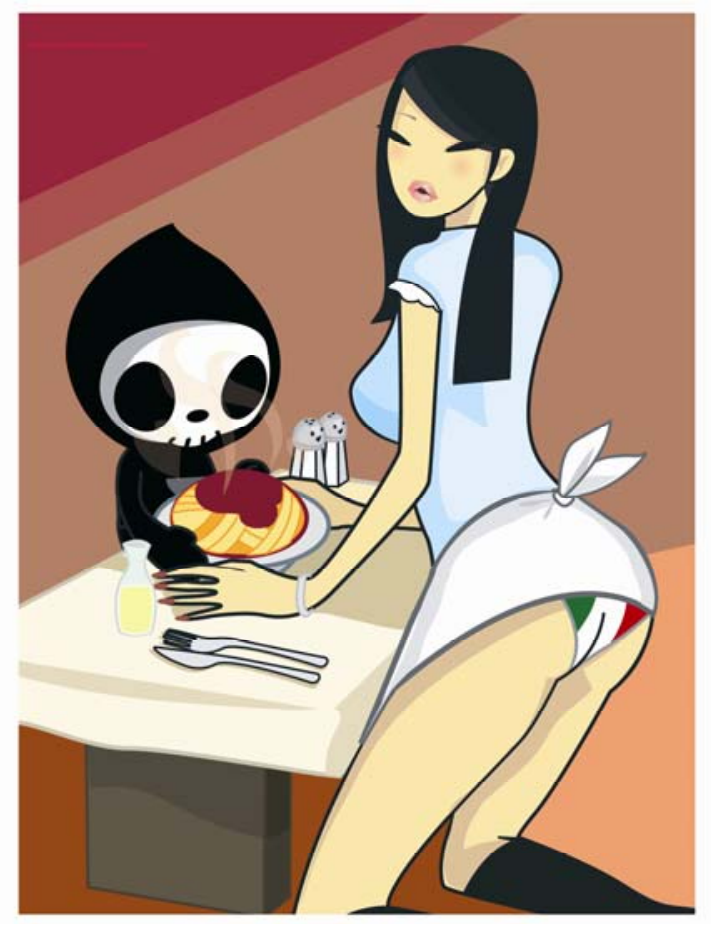

Figure 6. Japanese woman with Italian flag underwear, serving spaghetti to Death. The image is called Buonappetito.

This is not a provocative attempt to ridicule national symbols. Rather, it signals the transformation of boundaries across which conflicts erupt; thus, in Legno's cute decorative portrayal of an imaginary world, conflict seems to be not simply unacceptable, but impossible. On perhaps a more philosophical level, Legno transformed the traditional image of Death into two cute vinyl toys, Ciao Ciao (the skeleton-girl in pink) and Adios (the skeleton-boy in black) (Figure 4). There is a similar transformation in his reworkings of hell and heaven (Figures 2 and 3), represented as parallel and similarly cute worlds where the only, almost irrelevant, difference between them is that the woman is surrounded by cute angels (in heaven) and by demons (in hell). Even the Mafia is reinvented by Legno as an innocuous game in the series of milk box toys named Moofia, and in the cow with a sub-machine gun named Mozzarella (Figure 4).

Considering now the complex question about gendered Orientalism, it is noteworthy that the absence of male figures in the Tokidoki website and products masks the 
presence of its male creator. Murakami and Legno have achieved the unlikely marriage of innocence and sexuality by giving glamorous bodies to cute anime or manga faces. The absence of male figures indicates a difference in gender viewpoint at both creator and audience levels. In Murakami and Legno’s works, the objects of kawaii are always women or cute puppets. Men do not feature on the screen because they are the creators and viewers. The female figures in Murakami’s and Legno’s works, then, are the objects of their own fantasies and desires. Men want to possess them. In contrast, women are both objects and viewers. In other words, they want to be possessed and to possess the images. This basic understanding of Tokidoki is consistent with both the highly profitable “commodification of "racialised" and "sexualised” images typical of contemporary fashion' (Matthews 2007: 751-52), as well as the 'trajectory of Western racial and sexual imagery across the terrain of the female body’ (756).

The fact that the 'god' creator of this world is a Western man, however, should not lead to the conclusion that his representations of Asian women in a world without men are based on a typical racist uses of Asian women as a male Western answer to their threatened masculinity in contemporary society (Prasso 2005: 6). Nor should these representations be regarded as proof that 'Asian femininity becomes a marker of powerless, sexual exoticism and eroticism and by default whiteness becomes a signifier of power and superiority' (Matthews 2007: 759). Even the assumption that this kind of mono-gendered worlds is framed by a rigidly heterosexual perspective can, at least partially, be challenged. With regard to Tokidoki it is not simply that men want to see beautiful and exotic, yet submissive, women. Nor it is simply that many women accept this model in order to attract men. Rather this is an ambiguous matter that needs to be articulated in more nuanced terms.

When analysing Tokidoki images, many elements superficially support interpretations of Legno's work as characterised by a form of gendered Orientalism. Yet a high degree of ambiguity and contradictoriness characterises his design. Tokidoki women never gaze back at their spectators; their 'Oriental' eyes are small clefts and the pupils are never shown. This ensures that men can gaze at 'ideal' Japanese women who have a shy and sometimes submissive stance (Figures 7 and 8). This is clearly inconsistent with Japanese manga, where women's eyes are usually large and open. It is also clearly different from traditional Western productions (from TV ads to pornographic movies, 
including movies showing Asian women) that aim at arousing male desire: these represented women usually gaze back at men who, from a psychoanalytical point of view, are in fact objectified by the women’s gaze from the screen (Žižek and Salecl 1991).

It could be argued that this reading of Tokidoki's products would only make semiotic sense if the objects in question were consumed by men, as is often the case for soft and hard pornography. However, our impression is that while Tokidoki proposes a model of femininity created as a male fantasy, that model is directed toward a female audience of consumers. This apparent contradiction needs to be addressed.

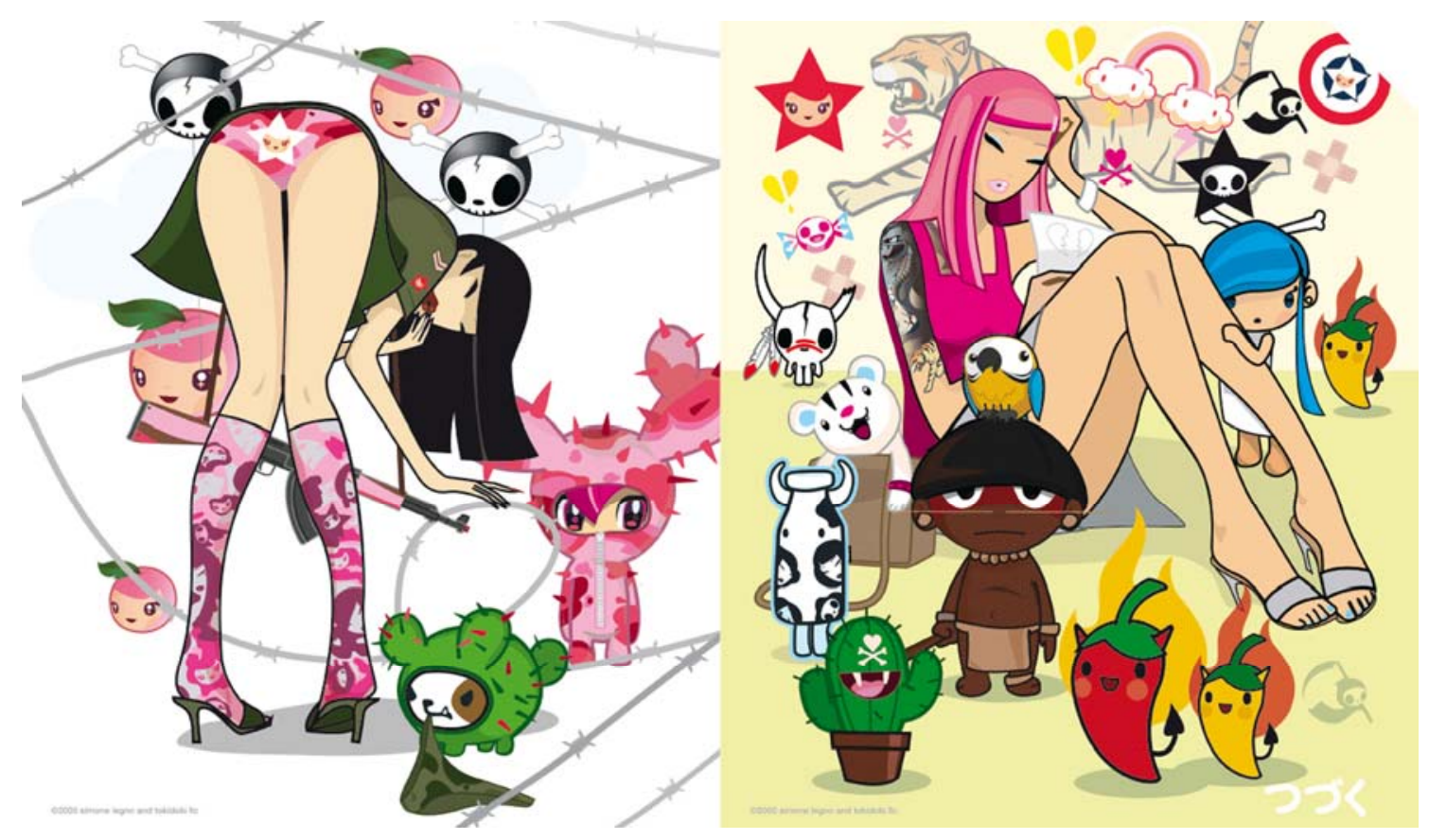

Figure 7. Other images of Tokidoki's women.

As evident in the images above (Figure 7), Tokidoki women often assume unnatural yet sexually evocative positions. For instance, by adopting a turned stance they show simultaneously their back, in particular their bottom and upper body, as well as their breasts and/or cute faces. Yet they rarely open their legs in a frontal position. This contributes to the refined sensuality of the image. These images 'want' to be provocative, yet they are not really 'available.' They are exotic, but their look also evokes the bodies of top models. They wear sexually alluring clothes, yet are never common or unrefined. They are gentle, perhaps even submissive, but ironically they are also self-confident, happy, and completely unavailable to the men they attract. Their 
world is full of cute puppets, angels, and toys, and in that world men are never represented. Indeed, Legno’s imagined world does not need men in order to be happy. The only Tokidoki image that we have found in which a man appears shows a kabuki actor's image tattooed on a woman's left arm. That image is representative of a theatrical world far removed from quotidian reality (figure 8). It could be argued, then, that these women are created to look sexually appealing while 'living' in a postheterosexual world. It is precisely around such an ambiguity that the success of Tokidoki revolves.

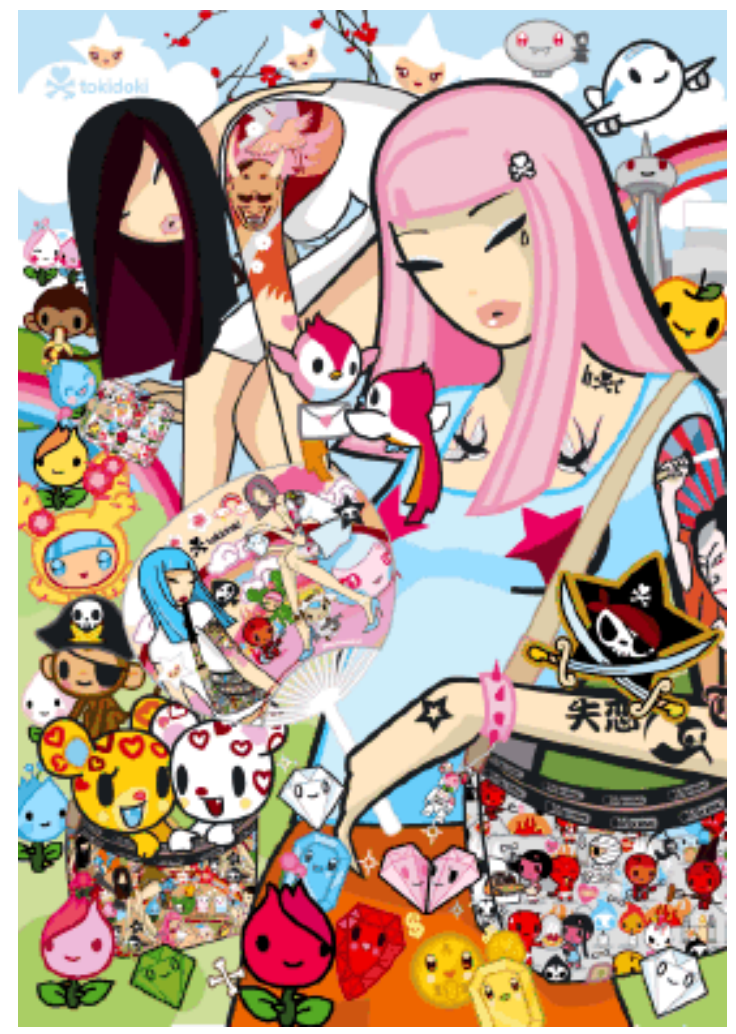

Figure 8. Kabuki actor tattooed on the left arm

It should not come as a surprise that this representation of ultra-feminine and reassuring, yet also independent and confident, women appeals first of all to female consumers. While it would be difficult to deny a degree of gendered Orientalisation in Legno's designs, we suggest that this model of femininity can also appeal to women who try to define and locate their identity in the liminal space between, on the one hand, a dominant and traditional heterosexuality, and, on the other, post-heterosexuality. By focusing on the ultra-feminine cuteness of Tokidoki's women, and the absence of men in the pictures in which those women appear, the emergence of post-heterosexual fantasies 
can be identified. This can be related to the phenomenon of the shōjo girls who, as Treat (1996: 281) explains, seem to extend their sexual interests toward puppets and kawaii objects. For Miller (2004: 156), 'the concept of shōjo implies an adolescent postpubescent space that revels in all that is cute, pink, fluffy, and adorable, with an absence of heterosexual experience.' Allison interprets this phenomenon on a more general level of consumption, emphasising how these girls 'pursue desires of self-pleasure by consuming clothes, accessories, music, and digital games' (2003: 387).

This is not to deny that Tokidoki can also be read as a masculinist appropriation of the feminine within a rigidly heteronormative perspective. On the contrary, these two apparently contradictory drives foster and sustain each other. Tokidoki production recalls a line of male Japanese illustrators who have contributed to the creation of ideal images of girls for fashion magazines, manga and stationery since the 1920s. Takehisa Yumeji (1884-1934) was the first modern artist to specialise in drawing young women in the 1920s and 1930s. He also created accessories, wrapping paper, advertisements and posters that were 'must-have' items among girls in the Taisho period (1920-1935). Nakahara Junichi (1913-1983), who succeeded Yumeji, worked for Junior Soreille (first published in 1953), the first Japanese fashion magazine to target teenagers. Nakahara's illustrations were highly influential among young Japanese girls, and some critics argue that they changed young women's values from wanting to be kirei (beautiful) to being kawaii (Suzuki 2004: 3). Since the early 1960s, Takahashi Makoto (born 1934) has created cover pages and illustrated stories for young girls’ comic books, such as Nakayoshi (first published 1954) and Margaret (first published 1963). His girls with starry eyes were, and remain, greatly admired by young readers. Again, male figures are invariably absent in the illustrations of these influential artists.

A relevant difference between the post-war illustrations of girls by Nakahara and Takahashi and Legno's illustrations, however, is the complete absence of sexuality in the former and the strong sensuality of the latter. Nakahara and Takahashi's girls were portrayed as pure and innocent, and free from daily chores, thus attracting young female readers who longed to be like them. Legno's innovation can be rigidly and superficially interpreted as a sexist tool only by ignoring the sexual, social and economic independence acquired by women in the last sixty years, not only globally, but also in 
Japan and progressively in many other Asian countries. ${ }^{13}$

Of course Legno is not the only representative of this new trend, which operates within a consolidated tradition. For example, in journalist Brian Bremner’s 2002 interview with Sato Kazuhiko, chief editor of Cawaii!, ${ }^{14}$ a magazine that targets a late-teen readership, Bremner asked Sato (a sociology graduate in his late forties) how a middleaged man can stay abreast with trend-happy Japanese girls and create images and consumer products that appeal to them. His answer was simple: he does not, but he employs young women who do. ${ }^{15}$ Here, one senses that the control and exploitation of kawaii culture regards that culture as a consumerist resource. Sato stresses that there is nothing either unhealthy or subversive about cute culture because, quite simply, 'girls are trying to be cute to get more attention from boys' (Bremner 2002: para.15). Yet this masculinist and heteronormative perspective may not correspond to that of Cawaii's female readers and consumers. Producers of commodities do not necessarily have control over, and understanding of, the reasons why their products are purchased and consumed. Kitty Hauser (2004: 19) has argued that what can be read as the 'playful expression of a fluid postmodernity' can also be seen as 'a depressing cul-de-sac in which consumption is the only remaining option.' When considering global phenomena, this ambiguity, and the infinite possibilities of agency on the part of different consumers across the world, should be kept in mind.

As Yomota (2006: 174) points out, the worldwide success of Japanese cute products cannot be explained if detached from the current epoch of globalisation. Riding on this wave of globalisation, assets the sociologist Iwabuchi, Japan's cultural exports in the last few decades partake of a certain 'cultural neutrality' (Iwabuchi 2001: 27). Iwabuchi lists karaoke, Walkman, and Murakami Haruki's novels as key examples, and stresses that they have entered the global market in exchange for their Japanese identity. This process may also apply to cute products. Hello Kitty was initially introduced to

\footnotetext{
13 It is worth recalling without ideological judgement that the Tokidoki world is a restrained one when compared, for instance, with the explicit violence and sexuality of Japanese 'Ladies' Comics,' successful pornographic manga created by women and for women, and in which women are routinely raped, beaten and humiliated (Jones 2005).

${ }^{14}$ Cawaii is an alternative romanisation of kawaii. Replacing an angular ' $\mathrm{K}$ ' with a round ' $\mathrm{C}$ ' gives a cuter impression (see, “What is cute?,” New York Times, January 3, 2006)

${ }^{15}$ In fact, many Japanese companies, including the mobile phone giant, DoCoMo, employ female work teams and focus groups to understand what the target consumers want (Miller 2003: para 18).
} 
Japanese consumers in the 1970s as signifying something ineffably Western, but it made little impact until the mid-1990s (Yomota 2006: 177). The cultural climate of the 1990s is also well illustrated by the rise of Hong Kong as an Asian centre for the global media industry and the expansion of the middle class in several Asian countries, notably China, Taiwan, and Korea. High-speed global communication, rising consumerism and cultural awareness in East Asia have all contributed to the spread of kawaii culture.

The Western reaction to kawaii culture has followed a different process in which two paths met. One is the changing concept of female beauty and childhood. The other is the emergence of a generation familiar with anime and manga. Okude Naohito (1987: 96116), a Japanese scholar of US culture, analyses the change in the popular image of 'American beauty' from the eighteenth to the twentieth centuries. He finds that the stereotypical American beauty with blond hair and a glamorous body, as embodied by Marilyn Monroe, is relatively new, and dates back only to the 1930s. Before that, beauty was represented predominantly by the genteel, dark-haired, slender, intelligent and sexually suppressed Anglo-Saxon woman. He lists Hollywood movies and Miss America contests, among other factors, as having influenced the reversal of this image. Girls from less privileged or migrant families started to appear on movie screens as symbols of a new multicultural America. By also embodying democracy and the 'American dream' they challenged prevailing class codes: one did not have to be from an old family to be 'beautiful.' Unlike the rather puritanical and traditional 'dark beauty,' the new Hollywood and Miss America models were not shy to show off their physical attributes as commodities. As these new gender models became popular and displaced the old ideal of American beauty, the notion that class superiority, stoic morality and intelligence were attached to 'dark hair' was also lost, ${ }^{16}$ thus creating a naïvely sensual, non-threatening blonde beauty.

Half a century after the rise of the blonde stereotype, television and the internet have pushed the popularisation of American beauty further and created a celebrity culture in which seemingly 'dumb, silly but cute' girls such as Paris Hilton, and the superficially dumb blonde, but smart, Elle Woods (a character in the 2001 film, Legally Blonde, played by Reese Witherspoon), have become role models. In a society where children

\footnotetext{
${ }^{16}$ Note, however, that according to Okude (1987: 110), these virtues became male attributes.
} 
were once expected to grow up and behave like adults on reaching maturity, cute blonde girls showed that it is socially acceptable to remain as children. In this context, America was ready to accept cute culture.

The anime generation, the other contributing force in the rise of Western cute culture, started as a minority interest group or sub-culture in the USA and elsewhere from the 1970s. Initially Japanese anime and manga were accepted by this generation as diverging sharply from the offerings of home grown Disney animation and US comic books. Their popularity grew rapidly as major television stations started to broadcast Japanese anime for US children in the 1970s. Later the successes of Hello Kitty, Pokemon and Dragon Ball in the 1990s were supported by a new generation of young Americans who grew up with imported Japanese pop culture and whose cultural sensibilities were, in part, cultivated by it. As well, the US music industry was quick to respond to the new trend with stars (such as Gwen Stefani) incorporating over-the-top Japanese fashion and cute features, and Japanese calligraphy, in their video clips. Thus, by the turn of the millennium 'cuteness' was well established in US popular culture.

The acceptance of cute culture in the USA was a result of the popularisation of an exaggerated girl-next-door beauty, the cultural prolonging of childhood and the introduction of anime to a new generation. Along with Legno's cute creatures, his women with Japanese faces and supermodel bodies symbolise the melding of Western popular beauty and cute culture. Just as European migration changed the US movie industry's s image of American beauty in the 1930s, Japanese pop culture, along with global television and the internet, are producing new images of cultural hybridisation. Legno's representation of Japanese women, then, is not really Japanese. What he produces, reinforces and complicates is a stereotype of the West's image of the Japanese woman with long straight black hair and slanted eyes. Few Japanese artists, in manga or fine art, would paint a Japanese woman’s face and body in the manner of Legno.

In this paper we do not want to sustain the essentialist myth that pure Japanese or Italian cultures and identities have been lost in the process of globalisation. More appropriate and interesting is to consider whether or not Tokidoki is emblematic of hybridising processes. Appadurai argues that 'the United States is no longer the puppeteer of a world system of images, but is only one node of a complex transnational construction of 
imaginary landscapes’ (2003: 29). When considered from Appadurai’s theoretical perspective, the Tokidoki world is one of the many 'imagined worlds' that comprise a global space of 'multiple worlds which are constituted by the historically situated imaginations of persons and groups spread around the globe' (2003: 31). As we have tried to demonstrate, Tokidoki has solid roots in consolidated stereotypes, in national traditions, in local forms of production and distribution, and in the continuous reinvention and commodification of femininity. The 'national' is here celebrated from the outside, from a transnational perspective that refuses to engage with national conflicts. If, as Morreal argues, cuteness is the feeling of tenderness and affection that the round, soft, vulnerable appearance of whelps produces in adult animals, so that whelps are nourished instead of being killed and eaten (Morreal 1991), then cuteness (kawaii, il carino) makes possible the 'soft' encounter of (invented) traditions and stereotypes that define different national cultures and identities.

Considering the statements posed at the beginning of this article, an ironic question could be asked. Will Italy ever be able to include artistic productions of the intellectual diaspora and global hybridisation, such as Legno’s Tokidoki, within its national rhetoric and cultural heritage? A more general, and perhaps more important, question is implied. Are Italian cultural and political institutions ready to reconsider Italian cultural traditions and artistic productions from a new perspective, by challenging the imaginary boundaries of the nation? 


\section{Reference List}

Allison, A. 2003, 'Portable Monsters and Commodity Cuteness: Pokémon as Japan’s New Global Power,' Postcolonial Studies, vol. 6, no. 3, 381-95.

Allison, A. 2004. 'Cuteness as Japan’s Millennial Product' in Pikachu's Global Adventure: The Rise and Fall of Pokemon, (ed.) J. Tobin, Durham and London, Duke University Press, 34-49.

Allison, A. 2006, Millenial Monsters: Japanese Toys and the Global Imagination, Berkeley and Los Angeles, University of California Press.

Anderson, B. 1991, Imagined Communities: Reflections on the Origin and Spread of Nationalism, Verso, New York and London.

Angier, N. 4 Jan. 2006, 'The Cute Factor,' New York Times Online, Available: http://www.nytimes.com/2006/01/03/science/03cute.html [Accessed 13 April 2008].

Appadurai, A. 1996, Modernity at Large: Cultural Dimensions of Globalisation, University of Minnesota Press, Minneapolis and London.

Appadurai, A. 2003, 'Disjuncture and Difference in the Global Cultural Economy,' in Theorizing Diaspora, (eds) A. Braziel and A. Mannur, Blackwell, Malden, MA, and Oxford, 25-48.

Benecchi, E. 2005, Anime: cartoni con l'anima, Hybris, Bologna.

Bhabha, H. 1994, The Location of Culture, Routledge, London and New York.

Bremner, B. 2002, 'Eye on Japan,’ BusinessWeek. Online, Available: http://www.businessweek.com/ bwdaily/dnflash/jun2002/nf20020625_7574.htm [Accessed 24 September 2007].

Castellazzi, D. 1999, Animeland: viaggio tra i cartoni made in Japan, Tarab, Firenze.

Funatsu, M. 2003, Takara \& Kaiyodo, artist Murakami Takashi no zokei o shokugan tenkai: Nanbaringu de 10 kaku 3 manko gentei hanbai. Online, Available: http://www.watch.impress.co.jp/game/docs/20031008/takara.htm [Accessed 23 January 2008].

Goh, B. 2004, 'Redrawing Centre-Periphery Relations: Theoretical Challenges in the Study of Southeast Asian Modernity,' in Asia in Europe Europe in Asia, (eds) S. Ravi, M. Rutten, and B. Goh, Institute of Southeast Asian Studies, Singapore, 79-101.

Hall, S. 2000, 'Cultural Identity and Diaspora,' in Diaspora and Visual Culture, (ed.) N. Mirzoeff, Routledge, London and New York, 21-33.

Hauser, K. 2004, 'Cute,' London Review of Books, 15 April, 19-20.

Hikosaka, N. 2008, Bijutsuka towa? Online, Available: http://hikosaka.blog.so-net.ne.jp/2008-01-26-1 [Accessed 12 March 2008].

Iwabuchi, K. 2001, Transnational Japan, Iwanami shoten, Tokyo.

Iwabuchi, K. 2002, Recentering Globalization: Popular Culture and Japanese Transnationalism, Duke University Press, Durham and London.

Jones, G. I. 2005, 'Bad Girls Like to Watch: Writing and Reading Ladies’ Comics,' in Bad Girls of Japan, (eds) L. Miller and J. Bardsley, Palgrave Macmillan, New York, 97-109.

Kato, M. 2002, Murakami Takashi o megutte: sono senryaku to jokyo ni tsuite. Online, Available: http://salsa.sakura.ne.jp/data/html/bunko/soturonyouyaku/20031126222639.html [Accessed 12 March 2008].

Kinsella, S. 1995, 'Cuties In Japan,’ in Women, Media and Consumption, (eds) L. Skov and B. Moeran, Curzon and Hawaii University Press, Hawaii, 220-54.

Kitani, S. 2001, Konkai no hakken, Murakami Takashi wa Kano-ha no matsuei da. Online, Available: http://www5.ocn.ne.jp/ sechiko/111murakami.htm [Accessed 12 April 2008].

Koh, B., Lee, B., Rickards, J., Notosusanto, T., Esaki-Smith and Drake, L. 1999, 'Cute Power!: Asia is in Love with Japan's Pop Culture. From Pokemon to Puffy, Japanese Stuff is oh, so “Q!” Stock up on those Hello Kitt Dumplings,' Newsweek International. Online, Available: http://www.newsweek.com [Accessed 4 June 2007].

Legno, S. n.d. About. Online, Available: http://www.tokidoki.it/about/ [Accessed 20 January 2008].

Legno, S. n.d. Pervasive Persuasion. Online, Available: http://blog.tokidoki.it/ [Accessed 17 January 2008].

Matthew, J. 2007, 'Deconstructing the Visual: The Diasporic Hybridity of Asian and Eurasian Female Images,' in Sociology of Diaspora, (eds) A.K. Sahoo and B. Maharaj, Rawat Publications, Jaipur, 749-70.

Miller, L. 2003, ‘Graffiti Photos: Expressive Art in Japanese Girls’ Culture,' Harvard Asia Quarterly. Online, Available: http://www.plum.com/Olivia.1126362/graffiti.1127760/harvardasia quarterlygraffitiphotosexpressiveartinjapanesegirls39culture.1710452?view=page [Accessed 13 Apr. 2008].

Miller, L. 2004, 'You are Doing Burikko!: Censoring/Scrutinizing Artificers of Cute Femininity in Japanese,' in Japanese Language, Gender, and Ideology: Cultural Models and Real People, (eds) 
S. Okamoto, J. Smith and J. S. Shibamoto, Oxford University Press, New York, 148-65.

Mirzoeff, N. 2000, 'Introduction: The Multiple Viewpoint: Diasporic Visual Cultures,' in Diaspora and Visual Culture, (ed.) N. Mirzoeff, Routledge, London and New York, 1-18.

Morreal. J. 1991, 'Cuteness,' British Journal of Aesthetics, vol. 31, no. 1, January, 39-47.

Murakami, T. 1999, PO+KU ART Revolution, Lecture given at Kyoto Seika University, 30 September, Online, Available: http://www.dnp.co.jp/museum/nmp/artscape/topics/9911/murakami/ murakami.html [Accessed 11 April 2008].

Okayama, E. and Shelton, B. 2006, 'Between Text and Pictures in Japan,' Visible Language, vol. 40, no. 2, 155-176.

Okude, N. 1987, 'Amerika bijin no ikoroji: Shion no musume kara Maririn Monro made,' Herumesu, Special Issue, no. 2, 96-116.

Pellitteri, M. 2002, Mazinga Nostalgia: storia, valori e linguaggi della Goldrake-generation, King, Rome.

Prasso. S. 2005, The Asian Mystique: Dragon Ladies, Geisha Girls and Our Fantasies of the Exotic Orient, Public Affairs, New York.

Raffaelli, L. 2005, Le anime disegnate: il pensiero nei cartoon da Disney ai giapponesi e oltre, Minimum Fax, Rome.

Ravi, S., Goh, L. and Rutten, M. 2004, 'Introduction,' in Asia in Europe Europe in Asia, (eds) S. Ravi, M. Rutten, and B. Goh, Institute of Southeast Asian studies, Singapore, 1-12.

Suzuki, T. 2004, Otome no himitsu oshiemasu Online, Available: http://media.excite.co.jp/book/news/topics/111/p05.html [Accessed 22 January 2008].

'Takashi Murakami.’ Kaikai Kiki Co. n.d. Online. Available: http://english.kaikaikiki.co.jp/artists/list/C4 [Accessed 22 January 2008].

TakashiMurakami.com n.d. Online. Available: http://www.takashimurakami.com/ [Accessed 22 January 2008].

ToPo. 2006, Tokidoki. Online, Available: http://art.commongate.com/post/Tokidoki\#images [Accessed 15 February 2008].

Treat, J. 1996, 'Yoshimoto Banana Writes Home: The shōjo in Japanese Popular Culture,' in Contemporary Japan and popular culture, (ed.) J. Treat, University of Hawaii Press, Honolulu, 275-308.

Washida, K. 2004, Kotoba no kao. Chuo koron shinsha, Tokyo.

Yomota, I. 2006, Kawaii ron. Chikuma shobo, Tokyo.

Žižek, S. \& Salecl, R. 1991, ‘Interview with Salvoj Žižek and Renata Salecl,’ Radical philosophy, no. 58, 25-31. 